\title{
Perbedaan MoL Bonggol Pisang dan EM4 sebagai Aktivator terhadap Lama Pengomposan Sampah dengan Metode Takakura
}

\author{
Zairinayati $^{{ }^{*}}$, Rahmi Garmini ${ }^{2}$ \\ *Email : zairinayati.kesling@gmail.com \\ Program Studi Kesehatan Lingkungan Fakultas Sains dan Teknologi \\ Institut Ilmu Kesehatan dan Teknologi Muhammadiyah Palembang
}

\begin{abstract}
Composting with the Takakura method is a simple waste management method, and can be used as an activator to speed up the decomposition process. Activators such as banana weevil and EM4 (Effective Microorganisms) can accelerate the composting process, because they contain Azotobacter sp., Lactobacillus sp., yeast, photosynthetic bacteria, and cellulose-degrading fungi, MoL (Local Microorganisms) is a collection of microorganisms that function to degrade organic molecules. This research was divided into three stages: MoL production, EM4 activation, and composting stage. The treatments were carried out using two takakura basket units, each with four replications, resulting in a total of eight samples and one control. The purpose of this study was to see whether with the Takakura technique, local microorganism of banana weevil and EM4 as an activator can reduce the time required for organic waste to become compost. This study uses quantitative techniques with experimental research design. The results showed that banana weevil MoL can be used as a compost activator and has the same ability as EM4 with a composting time of 21 days. The conclusion is that there is no difference between the use of banana weevil MoL with EM4 for composting using the Takakura method.
\end{abstract}

Keywords: MoL, EM4, compost

\section{ABSTRAK}

Pengomposan dengan metode Takakura merupakan metode pengolahan sampah yang sederhana, dan dapat dimanfaatkan sebagai aktivator untuk mempercepat proses penguraian. Aktivator seperti bonggol pisang dan EM4 (Effective Microorganism) dapat mempercepat proses pengomposan, karena mengandung Azotobacter sp., Lactobacillus sp., ragi, bakteri fotosintetik, dan jamur pendegradasi selulosa, MoL (Mikroorganisme Lokal) adalah kumpulan mikroorganisme yang berfungsi untuk mendegradasi molekul organik. Penelitian ini dibagi menjadi tiga tahap: pembuatan MoL, aktivasi EM4, dan tahap pengomposan. Perlakuan dilakukan menggunakan dua unit keranjang takakura, masing-masing dengan empat ulangan, sehingga total delapan sampel dan satu kontrol. Tujuan dari penelitian ini adalah untuk melihat apakah dengan teknik Takakura, mikroorganisme lokal bonggol pisang dan EM4 sebagai aktivator dapat mengurangi waktu yang dibutuhkan untuk sampah organik menjadi kompos. Penelitian ini menggunakan teknik kuantitatif dengan desain penelitian eksperimen. Hasil penelitian menunjukkan bahwa MoL bonggol pisang dapat digunakan sebagai aktivator kompos dan memiliki kemampuan yang sama dengan EM4 dengan waktu pengomposan 21 hari. Kesimpulan tidak ada perbedaan penggunaan MoL bonggol pisang dengan EM4 terhadap alam pengomposan dengan metode Takakura.

Kata Kuci: MoL, EM4, kompos 


\section{PENDAHULUAN}

Kegiatan kesehatan lingkungan sebagaimana tertuang dalam undangundang kesehatan bertujuan untuk menghasilkan lingkungan yang sehat, baik fisik, kimia, biologi, maupun sosial, yang memungkinkan setiap orang mencapai kesehatan yang sebaik-baiknya. Limbah cair, limbah padat, limbah gas, limbah yang tidak diolah sesuai ketentuan pemerintah, hewan pembawa penyakit, bahan kimia berbahaya, kebisingan yang melebihi nilai ambang batas, radiasi pengion dan non pengion, air tercemar, udara tercemar, dan makanan tercemar merupakan semua unsur yang dapat menimbulkan gangguan kesehatan. (Novela. V dkk, 2019)

Sistem pengelolaan sampah saat ini, yang didasarkan pada UU No. 18 Tahun 2008 dan PP No. 81 Tahun 2012, berfokus pada minimasi dan penanganan sampah. Pengurangan sampah terjadi dari sumberl sampai ke tempat pembuangan, dan dilakukan dengan partisipasi aktif dari masyarakat dan pihak pengelola sampah. (PP No. 81 tahun 2012, 2012)

Hal ini jika dibandingkan dengan sampah anorganik dan limbah yang mengandung bahan berbahaya, limbah organik domestik menyumbang bagian terbesar dari keseluruhan produksi limbah. Proses pengomposan dapat digunakan untuk mengolah sampah organik. Pengomposan adalah proses mengubah sampah organik menjadi senyawa yang stabil secara biologis yang mengandung komponen humus. Metode pengomposan keranjang takakura merupakan salah satu strategi pengomposan yang dapat digunakan. Metode pengomposan ini memiliki beberapa keunggulan dibandingkan sistem lainnya. Pertama prosesnya praktis karena sangat cocok untuk perumahan di area tanah yang kecil. Keranjang bisa diletakkan di mana saja, tergantung ketersediaan lahan, yang kedua adalah sederhana karena sampah hanya dimasukkan setipa hari, tanpa ada perawatan ekstra, seperti penambahan cairan atau bahan lainnya. Kemudahan yang beriktunya adalah karena prosesnya berjalan melalui fermentasi, sehingga bahan kompos tidak menimbulkan berbau. (A. Rezagama \& Samudro, 2015)

Mikroogranisme Lokal (MOL) dapat digunakan sebagai aktivator dalam salah satu proses pengomposan tersebut karena mengandung mikroba pengurai, seperti Effective Microorganisms (EM4), air cucian beras, air teh basi, dan MOL yang terbuat dari rebung, bonggol pisang, nanas, tomat, terasi, tapai, dan sisa sayur. Semua bahan tersebut dapat digunakan sebagai aktivator. (Ayu P, L, 2018) Mikroba pengurai atau bahan kimia yang berfungsi untuk mempercepat proses pengomposan digunakan sebagai aktivator. Selain mempercepat proses pengomposan, aktivator memastikan hasil pengomposan yang sempurna dan berkualitas tinggi karena mengandung unsur hara yang dibutuhkan tanaman. Penambahan aktivator MOL bonggol pisang dan EM4 pada penelitian memberikan pengaruh yang sangat nyata $(\mathrm{P}<0.01)$ terhadap P-total dan K-total. Hasil terbaik diperoleh ketika $35 \mathrm{~mL}$ MOL bonggol pisang ditambahkan ke dalam $5 \mathrm{~kg}$ bahan kompos (feses + kulit kopi; A3). (Karyono \& Yatno, 2017)

Waktu pengomposan dapat dipengaruhi oleh beberapa faktor, salah satunya adalah penggunaan mol dalam proses pengomposan. Pengomposan dengan campuran EM4 dan konsentrasi mol sebanyak $100 \mathrm{ml}$ membutuhkan durasi pengomposan 10 hari berdasarkan penelitian sebelumnya. Mikroorganisme lokal (MOL) dapat tumbuh subur pada setiap bahan organik yang mengandung nutrisi dan kelembaban yang cukup. Larutan MOL merupakan larutan fermentasi yang mengandung bahan baku 
berbagai sumber limbah organik, seperti bonggol pisang, keong mas, urin, limbah sayur, dan limbah buah. Bahan-bahan ini adalah media yang disukai mikroba untuk proses perkembangbiakannya. (Amalia. D, 2016)

Rata-rata waktu pengomposan dengan pengurai bonggol pisang adalah 14 hari, menurut penelitian sebelumnya. (Ramon, dkk, 2019) Mikroba pada bonggol pisang mendegradasi bahan organik. Pada bagian luar dan dalam bonggol pisang terdapat bakteri pengurai yaitu Bacillus sp., Aeromonas sp., dan Aspergillus nigger adalah beberapa mikroorganisme yang ditemukan dalam MOL bonggol pisang. Bahan organik sering diurai oleh bakteri ini. (Kesumaningwati, 2015) Penelitian lain menemukan bahwa penggunaan mikroorganisme indigen bonggol pisang dalam campuran kompos kotoran sapi dan kulit pinang memiliki pengaruh yang besar $(\mathrm{P}<0,05)$ terhadap fosfor, nitrogen, dan kalium dalam kompos, tetapi tidak berpengaruh $(\mathrm{P}>0,05)$ pada rasio $\mathrm{C} / \mathrm{N}$ atau $\mathrm{pH}$. Menurut temuan sebelumnya, penggunaan $\mathrm{MoL}$ bonggol pisang memiliki dampak yang signifikan terhadap jumlah waktu yang dibutuhkan untuk menghasilkan kompos dan kualitas kompos jika dibandingkan dengan pengomposan tanpa aktivator, yang memakan waktu 40 hari hingga 3 bulan. Studi lain mengklaim bahwa proses pengomposan alami memakan waktu lama, mulai dari 6 hingga 12 bulan, tergantung pada komposisi komponennya. Banyak bioaktivator telah dibuat untuk mempercepat proses degradasi dan dipasarkan dengan berbagai merek dagang komersial seperti EM4. Kompos yang dibuat menggunakan teknologi mikroba yang efektif akan mempercepat proses pematangan kompos, sehingga pengomposan dapat diselesaikan dalam waktu yang lebih singkat dibandingkan dengan metode tradisional. (Amalia. D, 2016)
Berdasarkan uraian latar belakang
diatas pada beberapa penelitian sebelumnya efektivitas dari mol EM4 terhadap pengomposan menggunakan metode biopori, penulis tertarik untuk melakukan penelitian tentang Perbedaan Mikroorganisme Lokal (MOL) Bonggol Pisang dan EM4 sebagai Aktifator terhadap lama pengomposan sampah organik dengan metode Takakura.

Penelitian ini bertujuan untuk mengetahui efektivitas dari MoL bonggol pisang sebagai aktivator dalam pengomposan. Kemampuan MoL ini dibandingkan dengan EM4 yang memang sudah diketahui sebagai produk yang berfungsi untuk mempercepat penguraian sampah. Sehingga peneliti tertarik untuk melakukan penelitian tentang pemanfaatan bonggol pisang menjadi MoL yang difermentasi dengan air gula merah dan air cucian beras kemudian diterapkan dalam pengomposan dengan metode Takakura.

\section{BAHAN DAN METODE}

Penelitian ini dilakukan dengan empat keranjang yang berisi MoL bonggol pisang, empat keranjang berisi EM4 dan satu kontrol untuk melihat efisiensi aktivator (EM4 dan MoL) pada waktu pengomposan sampah rumah tangga. Penelitian ini dilaksanakan pada bulan Agustus 2021.

Pembuatan MoL bonggol pisang merupakan langkah awal dalam penelitian ini, untuk membuat MoL dengan bonggol pisang sebagai bahan baku, tahap pertama adalah mencampurkan 2 kilogram bonggol pisang yang sudah dihaluskan dengan 100 gram gula merah encer (sebagai pengurai) dan 2 liter air cucian beras, aduk hingga rata dan gula larut. Campuran tersebut kemudian dimasukkan ke dalam jerigen dan ditutup kemudian didiamkan selama 10-15 hari sebelum disaring. 
Aktivasi EM 4 dilakukan pada tahap kedua dengan mencampurkan 500 ml EM4 asli dengan $500 \mathrm{ml}$ molase (larutan gula), kemudian menambahkan air hingga campuran mencapai $1500 \mathrm{ml}$, kemudian menuangkan larutan tersebut ke dalam wadah dan menutup rapat tutupnya. Biarkan dalam wadah kedap udara selama 5-10 hari, wadah harus tertutup rapat dan dijauhkan dari sinar matahari langsung. Pada hari kelima, buka tutup wadah untuk mengeluarkan gas agar tidak pecah, setelah 5-10 hari EM4 aktif dapat digunakan dengan aroma manis dan asam. pH EM4 aktif adalah antara 3,5 dan 3,7.

Proses pengomposan adalah tahap ketiga, kompos dibuat dengan dua cara. Perlakuan I menggunakan MoL bonggol pisang sebagai aktivator, sedangkan perlakuan II menggunakan EM4. Setiap perlakuan diolah dalam dua keranjang Takakura dengan empat kali ulangan, menghasilkan delapan sampel dan satu kontrol. Proses pengomposan dilakukan dengan menyiapkan bahan kompos berupa sampah $5 \mathrm{~kg}$ sayuran dibeli dari pedagang pasar, sampah organik ini ditimbang dan dicincang, sebagai perlakuan pertama, limbah organik cacahan dicampur dengan air, gula, dan aktivator bonggol pisang, dilanjutkan dengan penambahan EM4 sebagai perlakuan kedua, dan satu kontrol. Bentuk bahan baku kompos yaitu sampah sayuran dan daun kering dengan perbandingan komposisi $1 \mathrm{~kg}: 0,8 \mathrm{~kg}$ (berdasarkan perhitungan Departemen Pertanian dan Pangan, 1998).

\section{HASIL DAN PEMBAHASAN}

Tabel 1. Hasil Pengamatan Kematangan Kompos terhadap Parameter Fisik Kompos (warna, tekstur dan bau) dan penyusutan volume kompos menggunakan dekomposer Effektif Mikroorganisme (EM4)

\begin{tabular}{llll}
\hline \multirow{2}{*}{ Parameter } & \multicolumn{3}{c}{ Waktu Pengamatan } \\
\cline { 2 - 4 } Warna & Minggu pertama & Minggu kedua & Minggu ketiga \\
Tekstur & Meklat & Coklat & Coklat kehitaman \\
Bau & $\begin{array}{l}\text { Sampah daun mulai mengecil, } \\
\text { Bau nadah terurai }\end{array}$ & Remah \\
& $\begin{array}{l}\text { Bau decompo } \\
\text { ser dan sampah, lembek }\end{array}$ & Bau tanah \\
\hline
\end{tabular}

Tabel. 1 diatas menunjukkan bahwa selama pengamatan, dilakukan pembalikan dan penyiraman setiap 3 hari sekali untuk menjaga kondisi bakteri pengurai tetap hidup. Pada minggu ke-2 kondisi tekstur kompos telah terjadi penguraian dibuktikan dengan daun sudah mulai menghitam dan ukurannya mengecil, untuk bau pada minggu ke-2 bau kompos sudah berbau tanah. Masuk pada minggu ke-3 warna kompos sudah coklat kehitaman, teksturnya remah, gembur dan baunya sudah berbau tanah. 
Tabel 2. Hasil Pengamatan Kematangan Kompos terhadap Parameter Fisik Kompos (warna, tekstur dan bau) dan penyusutan volume kompos menggunakan dekomposer MoL Bonggol Pisang

\begin{tabular}{|c|c|c|c|}
\hline \multirow{2}{*}{ Parameter } & \multicolumn{3}{|c|}{ Waktu Pengamatan } \\
\hline & Minggu pertama & Minggu kedua & Minggu ketiga \\
\hline Warna & Coklat & Coklat kehitaman & Coklat kehitaman \\
\hline Tekstur & Menggumpal & Remah & Remah, gembur \\
\hline Bau & $\begin{array}{l}\text { Bau dekomposer dan sampah, } \\
\text { lembek }\end{array}$ & Bau tanah & Bau tanah \\
\hline
\end{tabular}

Tabel. 2 menunjukkan bahwa selama pengamatan sama halnya dengan perlakukan pada tabel. 1 yaitu dilakukan pembalikan dan penyiraman setiap 3 hari sekali untuk menjaga kondisi bakteri pengurai tetap hidup. Kompos diasumsikan telah matang dan siap digunakan dengan indikasi warna sudah coklat kehitaman seperti warna tanah, teksturnya remah, gembur, dan tidak berbau pada minggu ke-3. Secara umum peran bakteri pengurai sangat menentukan kematangan kompos, dengan metode Takakura diperoleh gambaran bahwa mulai dari tahap pembuatan starter/decomposer, dilanjutkan dengan pembuatan tempat pembiakan bakteri (TPB) terbukti di hari ke-3 sudah terbentuk jamur yang tumbuh dipermukaan (TPB) hal ini menunjukkan bahwa TPB sudah siap ditambahkan sampah organik untuk pengomposan.

Proses pengomposan dilakukan selama 21 hari dengan memanfaatkan metode takakura menggunakan pengurai bonggol pisang EM4 dan MoL. Sebelum menggunakan dekomposer, bahan baku awalnya ditempatkan dalam larutan gula untuk memberikan nutrisi bakteri untuk dekomposisi. EM4 dicampur dengan air gula, dan tongkol pisang dicampur dengan kombinasi gula merah, air cucian beras. Karena aktivitas mikroba mulai mencapai puncaknya selama pengomposan, suhu terus meningkat. Mikroorganisme memiliki peran penting dalam proses pengomposan secara teori. Mikroorganisme golongan mesofilik lebih banyak bekerja karena aktivitasnya menghasilkan panas yang menaikkan suhu di atas $40^{\circ} \mathrm{C}$. Seiring dengan penurunan bahan organik yang tersedia, aktivitas mikroba secara bertahap akan menurun.

Berdasarkan hasil penelitian yang dilakukan oleh Benito 2012 menunjukkan bahwa bakteri yang diisolasi dan diidentifikasi pada awal proses pengomposan adalah Enterobacter sp dan Escherichia coli. Bakteri ini termasuk dalam kelompok bakteri mesofilik yang tumbuh subur di lingkungan asam, dan ditemukan pada saat proses pengomposan seperti Bacillus sp. Namun keberadaan bakteri jenis ini dapat membunuh bakteri dari kelompok Escherichia coli, Pseudomonas sp, dan Enterobacter yang merupakan bakteri patogen. Namun, pada akhir proses pengomposan, setelah penurunan suhu menjadi mesofilik, memungkinkan Enterobacter $s p$. dan bakteri Escherichia coli muncul kembali dalam jumlah kecil. (Benito, 2012)

$$
\text { Media pengomposan masih }
$$
berbau seperti bahan baku yaitu bau dekomposer, serta bahan baku sampah organik yaitu sisa sayuran dan tambahan beras dan sisa-sisa daun, pada awal proses pengomposan. saat semua bahan organik dalam kompos sudah matang, telah terurai dan siap digunakan, maka akan tercium bau tanah.

Warna kompos untuk dua perlakuan, aktivator MoL bonggol pisang dan EM4, menunjukkan perubahan yang bertahap pada awal pengomposan bahan kompos masih berwarna coklat, tetapi pada minggu kedua sudah mulai berubah warna. Warna kompos dengan MoL 
bonggol pisang berubah dari coklat menjadi hitam pada minggu kedua. Menurut penelitian sebelumnya, perubahan warna disebabkan oleh mikroba pengurai bahan organik yang mengandung rantai $\mathrm{C}$ yang kompleks dan mengubahnya menjadi bentuk $\mathrm{C}$ sederhana. Bahan kompos, seperti serasah daun mengalami perubahan karena kehilangan pigmen warna saat terurai, dan warnanya berubah menjadi hitam tergantung pada warna bagian penyusunnya. Aktivitas mikroba pengurai berkontribusi pada fase ini dengan mengambil air, oksigen, dan nutrisi dari bahan organik, yang kemudian didekomposisi. (Kumalasari, 2016)

Hasil pengamatan terhadap tekstur kompos didapatkan bahwa pada kondisi awal bahan kompos lembek dan sedikit menggumpal karena penyiraman dekomposer, pada minggu kedua tekstur sampah sudah mulai hancur namun masih sedikit kasar, ukurannya mulai mengecil dan volumenya menurun karena kadar air sudah berkurang, saat penelitian berlangsung bahan kompos dilakukan pembalikan untuk menjaga sirkulasi oksigen. Kondisi ini menunjukkan bahwa aktivitas bakteri pengurai golongan mesofilik berkerja dengan maksimal terbukti diawal persiapan pembuatan tempat pembiakan bakteri sebagai media pengomposan dengan Takakura sudah menunjukkan aktivitas bakteri yang baik dengan munculnya jamur disetiap keranjang pengamatan, pembiakan bakteri ini berlangsung selama 3 hari. Proses pengomposan juga menggunakan sekam padi tujuannya adalah untuk menjaga sirkulasi udara dan sebagai media tempat hidupnya bakteri. Sekam juga dapat digunakan untuk mempercepat proses pengomposan, bakteri akan cepat berkembang biak, hal ini sebagaimana hasil penelitian sebelumnya bahwa penambahan sekam dapat mempercepat penguraian karena sekam berperan sebagai penyusun polimer polisakarida.
Bahan lain juga adalah penambahan bekatul yang bertujuan untuk menambah jumlah mikroorganisme. Kerja mikroorganisme sangat ditentukan oleh ketersediaan nutrisi, jika nutrisi kurang maka mikroorganisme akan mengurangi aktivitsnya begitupun sebaliknya dan sekam menjadi sumber nutrisinya. (S. Rezagama, 2015)

Kompos yang dibuat selama 21 hari menunjukkan perubahan warna, tekstur, dan bau dari kompos yang sudah mulai masak sesuai SNI 19-7030-2004, yaitu berwarna coklat kehitaman, bertekstur, dan berbau seperti kotoran. Hal ini sesuai dengan penelitian metode Takakura sebelumnya, yang menemukan bahwa pengomposan dengan $45 \mathrm{ml}$ air cucian beras pada hari ke-19 kompos sudah matang dan dapat digunakan, pada pengomposan dengan $30 \mathrm{ml}$ air cucian beras matang pada hari ke-23, dan pengomposan dengan $20 \mathrm{ml}$ air cucian beras, pada hari ke-27 menunjukkan hasil terbaik. Pada kontrol bahan kompos diberi air biasa, dan pada hari ke 33, warna kompos berubah menjadi coklat kehitaman, bau kompos berubah menyerupai aroma tanah, dan volume kompos berkurang. .

\section{KESIMPULAN}

Kesimpulan pada penelitian ini bahwa penggunaan Mikroorganisme Lokal (MoL) dari bonggol pisang terhadap lama waktu pengomposan sampah dengan metode Takakura didapatkan bahwa tidak ada perbedaan penggunaan $\mathrm{MoL}$ bonggol pisang dengan EM4 terhadap lama pengomposan dengan metode Takakura. Disarankan pada penelitian berikutnya perlu pengamatan terkait dosis efektif dalam penggunaan MoL bonggol pisang terhadap kemampuannya menguraikan sampah.

\section{Ucapan Terima Kasih}

$\begin{array}{lll} & \text { Penulis mengucapakan } & \text { terima } \\ \text { kasih kepada Rektor } & \text { IKesT } \\ \text { Muhammadiyah Palembang, } & \text { Dekan }\end{array}$


Fakultas Sains dan Teknologi, Ketua Program Studi Diploma III Kesehatan Lingkungan dan Kepala Lembaga Penelitian, Pengabdian Masyarakat dan Inovasi (LP2MI), yang telah memberikan kesempatan dan dukungan baik moral maupun materiil kepada peneliti sehingga penelitian ini dapat diselesaikan tepat waktu.

\section{DAFTAR PUSTAKA}

Amalia. D, W. P. (2016). Penggunaan EM4 dan MOL Limbah Tomat sebagai Bioaktivator pada Pembuatan Kompos. Jurnal Life Science Unnes, 5(1), 18-24.

Ayu P, L, dkk. (2018). Pengaruh Frekuensi Penyiraman Air Limbah CUcian BEras terhadap Lama Waktu PEngomposan dengan Metode Lubang Resapan Biopori.

Benito, A. . dkk. (2012). Identifikasi Bakteri yang Dominan Berperan pada Proses Pengomposan Filtrate Pengolahan Pupuk Cair Feses Domba ( Identification of Dominant Bacteria in The Composting of Filtrate of Liquid Fertilizer Making Process of Sheep Feces ). Jurnal Ilmu Ternak, 12(1), 7-10.

Karyono, T., \& Yatno. (2017). Penambahan Aktivator Mol Bonggol Pisang dan EM 4 dalam Campuran Feses Sapi Potong dan Kulit Kopi terhadap Kualitas Kompos dan Hasil Panen Pertama Rumput Setaria ( Setaria splendida Stapf ) Mol Banana Weevil Bio Activator Addition and EM4 in a Mixture of C. Jurnal Sains Peternakan Indonesia, 12(1), 102-111.

Kesumaningwati, R. (2015). Penggunaan Mol Bonggol Pisang (Musa Paradisiaca) Sebagai Dekomposer Untuk Pengomposan Tandan Kosong Kelapa Sawit. Journal of Chemical Information and Modeling, 40(1), 40-45.
Kumalasari, R. (2016). Pengomposan daun menggunakan konsorsium Azotobacter. Jurnal Sains Dan Seni ITS, 5(2), 7-9.

Novela. V dkk. (2019). Efektivitas Aktivator EM4 dan MOL Tape Singkong Dalam Pembuatan Kompos Dari Sampah Pasar (Organik) Di Nagari Kototinggi. Jurnal Human Care, 3(2), 1-9.

PP No. 81 tahun 2012. (2012). tentang Pengelolaan Sampah Rumah Tangga dan Sampah Sejenis Sampah Rumah Tangga.

Rezagama, A., \& Samudro, G. (2015). Studi Optimasi Takakura Dengan Penambahan Sekam Dan Bekatul. Jurnal Presipitasi: Media Komunikasi Dan Pengembangan Teknik Lingkungan, 12(2), 66. https://doi.org/10.14710/presipitasi.v 12i2.66-70

Wulandari. (2004). Pasar Nanggalo Kota Padang merupakan Pada umumnya masyarakat memenuhi kebutuhan pangan. Prosiding Semianr Nasional STIKEs Syedza Saintika, 475-487. 